\title{
Abrupt climate and vegetation variability of eastern Anatolia during the last glacial
}

\author{
N. Pickarski ${ }^{1}$, O. Kwiecien ${ }^{2}$, D. Langgut ${ }^{3}$, and T. Litt ${ }^{1}$ \\ ${ }^{1}$ University of Bonn, Steinmann Institute for Geology, Mineralogy, and Paleontology, Bonn, Germany \\ ${ }^{2}$ Ruhr-University Bochum, Sediment and Isotope Geology, Bochum, Germany \\ ${ }^{3}$ Tel Aviv University, Institute of Archaeology, Tel Aviv, Israel \\ Correspondence to: N. Pickarski (pickarski@uni-bonn.de)
}

Received: 24 June 2015 - Published in Clim. Past Discuss.: 22 July 2015

Revised: October 2015 - Accepted: 21 October 2015 - Published: 2 November 2015

\begin{abstract}
Detailed analyses of the Lake Van pollen, $\mathrm{Ca} / \mathrm{K}$ ratio, and stable oxygen isotope record allow the identification of millennial-scale vegetation and environmental changes in eastern Anatolia throughout the last glacial $(\sim 111.5-11.7 \mathrm{ka} \mathrm{BP})$. The climate of the last glacial was cold and dry, indicated by low arboreal pollen (AP) levels. The driest and coldest period corresponds to Marine Isotope Stage (MIS) 2 ( 28-14.5 ka BP), which was dominated by highest values of xerophytic steppe vegetation.

Our high-resolution multi-proxy record shows rapid expansions and contractions of tree populations that reflect variability in temperature and moisture availability. These rapid vegetation and environmental changes can be related to the stadial-interstadial pattern of Dansgaard-Oeschger (DO) events as recorded in the Greenland ice cores. Periods of reduced moisture availability were characterized by enhanced occurrence of xerophytic species and high terrigenous input from the Lake Van catchment area. Furthermore, the comparison with the marine realm reveals that the complex atmosphere-ocean interaction can be explained by the strength and position of the westerlies, which are responsible for the supply of humidity in eastern Anatolia. Influenced by the diverse topography of the Lake Van catchment, more pronounced DO interstadials (e.g., DO 19, 17-16, 14, 12 and 8) show the strongest expansion of temperate species within the last glacial. However, Heinrich events (HE), characterized by highest concentrations of ice-rafted debris (IRD) in marine sediments, cannot be separated from other DO stadials based on the vegetation composition in eastern Anatolia. In addition, this work is a first attempt to establish a continuous microscopic charcoal record for the last glacial in the Near East.
\end{abstract}

It documents an immediate response to millennial-scale climate and environmental variability and enables us to shed light on the history of fire activity during the last glacial.

\section{Introduction}

The last glacial inception was marked by the expansion of continental ice sheets and substantial changes in oceanographic conditions in the North Atlantic as well as in atmospheric temperature and moisture balance in the Northern Hemisphere (e.g., Blunier and Brook, 2001; Cacho et al., 2000, 1999; Chapman and Shackleton, 1999; Rasmussen et al., 2014; Sánchez Goñi et al., 2002; Svensson et al., 2008, 2006; Wolff et al., 2010). Between Marine Isotope Stages (MIS) $5 \mathrm{~d}$ and 2, the climatic conditions were characterized by numerous abrupt millennial-scale oscillations, known as Dansgaard-Oeschger events (DO; Dansgaard et al., 1993). These are most prominently documented in Greenland ice cores and exhibit an abrupt warming (Greenland interstadials; GI), followed by a gradual cooling and a final rapid temperature drop towards a cold Greenland stadial (GS; e.g., NGRIP members, 2004; Rasmussen et al., 2014; Svensson et al., 2008; Wolff et al., 2010). About 25 such stadial to interstadial transitions, varying in amplitude from 5 to $16^{\circ} \mathrm{C}$, are defined in the NGRIP record during the last glacial period (NGRIP members, 2004; Rasmussen et al., 2014; Wolff et al., 2010). Although the climatic and environmental impacts of the DO cycles have been intensively studied during the last decades, the mechanism behind them is still under debate (e.g., Cacho et al., 2000, 1999; Rasmussen et al., 
2014; Wolff et al., 2010). The main process proposed as a cause for the recurring pattern is freshwater being forced from ice-sheets that affected the extent of the sea ice, ocean heat transport, and Atlantic Meridional Overturning Circulation (AMOC; Bond and Lotti, 1995; Cacho et al., 2000, 1999; Chapman and Shackleton, 1999; Hemming, 2004; Hodell et al., 2008; McManus et al., 1999; Rasmussen et al., 2014; Wolff et al., 2010). The most extreme cold intervals are Heinrich events (HE; Bond et al., 1993, 1992, Heinrich, 1988), characterized by reduced sea surface temperatures (SST; Cacho et al., 1999) with highest concentrations of ice-rafted debris (IRD) in marine sediments due to massive iceberg discharges, which mainly originated from the Laurentide ice sheet (Alvarez-Solas and Ramstein, 2011).

Long-term terrestrial pollen records from the central and eastern Mediterranean, for example several crater lakes in Italy (e.g., Lagaccione, Lago di Vico, Lazio Valle di Castiglione, Stracciacappa; Follieri et al., 1998), Lago Grande di Monticchio (Italy; e.g., Allen et al., 1999), Lake Prespa (between Albania, Republic of Macedonia, and Greece; Panagiotopoulos et al., 2014), Lake Ohrid (Albania; Lézine et al., 2010) and Tenaghi Philippon (Greece; e.g., Müller et al., 2011) demonstrate a clear vegetation response to millennialscale climate variability during the last glacial. These regions are highly sensitive to short-term vegetation changes as recognized by steppe-dominated open landscapes during stadials and increased range of temperate tree taxa during interstadials (e.g., Allen et al., 2000, 1999; Follieri et al., 1998; Langgut et al., 2011; Lézine et al., 2010; Müller et al., 2011; Panagiotopoulos et al., 2014; Shumilovskikh et al., 2014). In contrast to southern Europe, high-resolution and continuous terrestrial sedimentary records displaying abrupt climate oscillations are rare in the entire Near East.

Since the first long lacustrine sediment sequences were recovered at Lake Van in summer 2010 (Litt and Anselmetti, 2014; Litt et al., 2012), numerous high-resolution data have been gathered, providing insight into short-term changes in past climatic and environmental conditions in eastern Anatolia (e.g., XRF measurements described by Kwiecien et al., 2014; total organic carbon content (TOC), Stockhecke et al., 2014a). The sensitivity of this region was already welldocumented by previous palynological data sets covering the Late Glacial and the Holocene periods (Litt et al., 2009; Wick et al., 2003). First pollen results of the new $\sim 219 \mathrm{~m}$ long composite profile encompassing the last $600 \mathrm{ka}$, have been described based on lower temporal resolution (between $\sim 900$ and 3800 years) by Litt et al. (2014). A detailed highresolution pollen analysis (between $\sim 100$ and 800 years) for the last interglacial (131.2-111.5 ka BP) is documented in Pickarski et al. (2015).

Here we present new biotic data (pollen, microscopic charcoal remains) and combine them with already available Lake Van abiotic proxies (stable oxygen isotope and element measurements) of the last glacial period ( $\sim 111.5-11.7 \mathrm{kaBP})$. Special focus is given to the centennial- to millennial-scale climate variability, as known from Greenland, and the regional response of vegetation to abrupt paleoenvironmental changes in eastern Anatolia. After the examination of climate and vegetation changes on a local level, we compare our results to selected global reference archives. Furthermore, we provide the first continuous sedimentary microscopic charcoal record from Lake Van to give insights into the coupling and feedback between fire activity and major changes in climate, vegetation, and fuel amount during the last glacial.

\section{Regional setting}

Lake Van $\left(38.6^{\circ} \mathrm{N}, 42.8^{\circ} \mathrm{E}\right)$ is a deep terminal alkaline lake ( $3574 \mathrm{~km}^{2}$; max. depth $>450 \mathrm{~m}$ ) situated on the eastern Anatolian high plateau at $1647 \mathrm{~m}$ above sea level (a.s.l., Fig. 1). It is the largest soda lake in the world (Degens and Kurtman, 1978), which is partly fed by numerous small rivers around the basin. In the south, the lake is surrounded by the Bitlis Massif reaching altitudes of more than $3500 \mathrm{~m}$ a.s.l. Two large active stratovolcanoes, Nemrut (2948 m a.s.1.) and Süphan (4058 $\mathrm{m}$ a.s.1.), border the lake to the west and north (Fig. 1b).

The present-day climate of eastern Anatolia is controlled by seasonal changes in the position and strength of the following atmospheric components: (a) the mid-latitude westerlies, (b) the sub-tropical high-pressure system, and (c) the Siberian high-pressure system (Akçar and Schlüchter, 2005; Türkeş, 1996). The regional climate at Lake Van is continental with warm and dry summers (mean temperature $>20^{\circ} \mathrm{C}$; Turkish State Meteorological Service) and cold and wet winters, marked by regular frosts. The minimum average temperature of the coldest month is far below $0{ }^{\circ} \mathrm{C}\left(-7.9^{\circ} \mathrm{C}\right.$ in Van; see Fig. $1 \mathrm{~b}$ for the location). Total rainfall varies from $385 \mathrm{~mm} \mathrm{a}^{-1}$ (Van) to $816 \mathrm{~mm} \mathrm{a}^{-1}$ (Tatvan) and peaks in the winter months (October to February), with a second rainfall maximum during spring (March to May). Higher elevations of the west-east oriented mountain ranges along the Bitlis Massif (Fig. 1b) are affected by the strength and position of the "Cyprus cyclones" from the Mediterranean Sea with precipitation values up to $1200 \mathrm{~mm} \mathrm{a}^{-1}$ in Bitlis (Turkish State Meteorological Service; Litt et al., 2014).

The modern distribution of vegetation at Lake Van is closely related to rough orography and spatial rainfall variability. The southward slopes of the Bitlis Massif are covered by the Kurdo-Zagrosian oak steppe-forest (Quercetea brantii), which extends from the Taurus Mountains (east-central Turkey) via the Bitlis complex (SW shore of Lake Van) to the Zagros Mountains (SW Iran; Zohary, 1973). It consists of several oak species, which are accompanied by Pistacia atlantica, P. khinjuk, Acer monsplessulanum, Juniperus oxycedrus, Pyrus syriaca, Crataegus spp., Prunus and Amygdalus spp. (Frey and Kürschner, 1989). In the rain-shadow, where rainfall decreases drastically, the north-eastern part of the lake drainage is covered by Irano-Turanian steppe vegetation, 


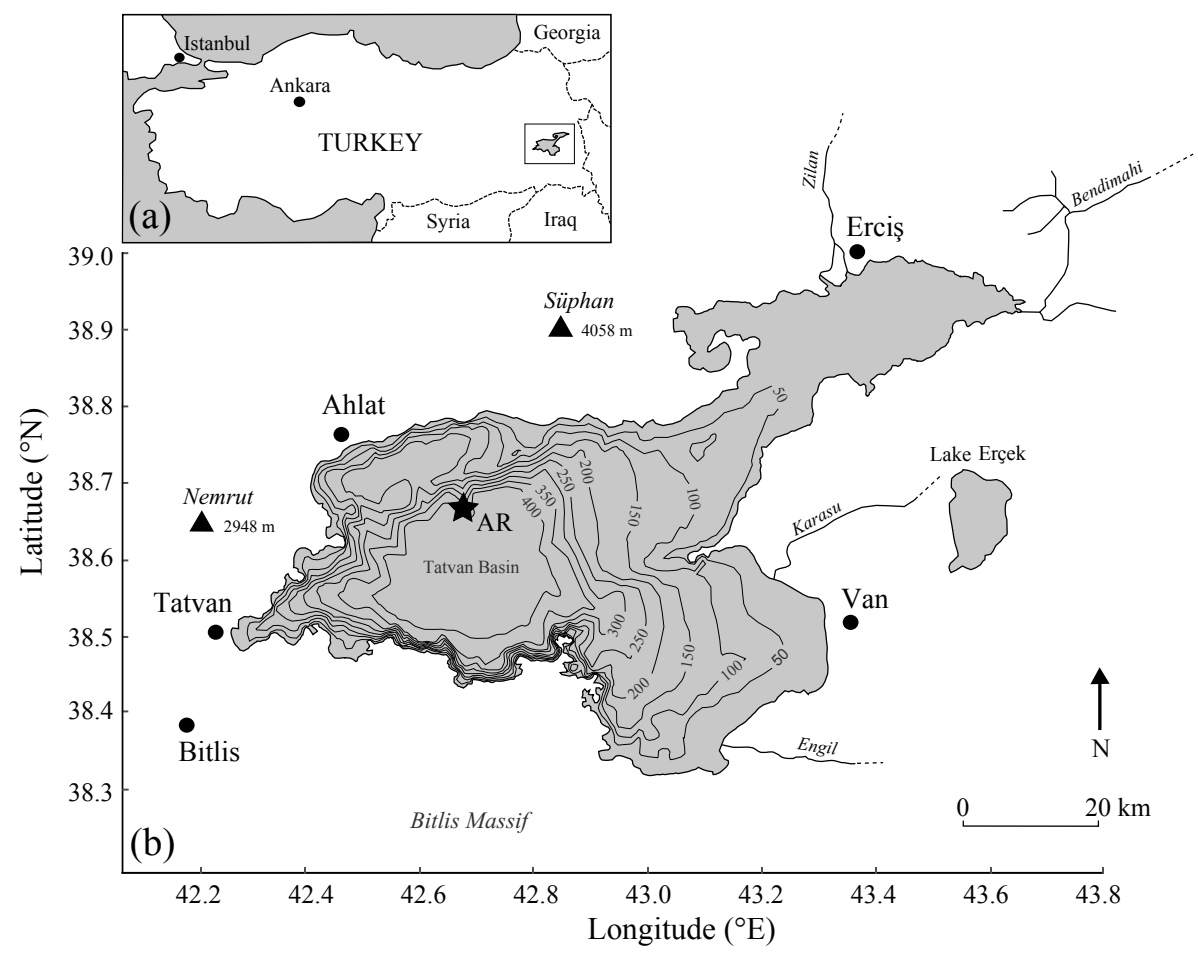

Figure 1. (a) Location of Lake Van in eastern Anatolia (Turkey) and (b) the bathymetry of Lake Van including the main ICDP drill site Ahlat Ridge (AR, black star). Major cities (black dots) and rivers are represented. The black triangle indicates the positions of the active volcanoes Nemrut and Süphan. The Bitlis Massif in the south reaches up to $3500 \mathrm{~m}$ a.s.1.

dominated by Artemisia fragrans, steppe forbs and grasses (Zohary, 1973).

\section{Material and methods}

Sedimentary record "AR" (Ahlat Ridge; $38.667^{\circ} \mathrm{N}$, $42.669^{\circ} \mathrm{E} ; 357 \mathrm{~m}$ water depth) was collected on a bathymetric ridge in the northern part of the Tatvan Basin (Fig. 1b) during the ICDP (International Continental Scientific Drilling Program) project PALEOVAN in summer 2010 (Litt and Anselmetti, 2014; Litt et al., 2012). Here we present data of the uppermost $3.87-41.72 \mathrm{~m}$ of the event-corrected composite record (mcblf-nE; depth scale, which excludes volcanic ash layers and mass flow deposits; Stockhecke et al., 2014a), representing the time span from 9.48-111.39 ka BP.

\subsection{Chronology}

The chronology of the Lake Van sedimentary sequence is based on independent proxy records, e.g., high-resolution XRF measurements (Kwiecien et al., 2014), total organic carbon (TOC; Stockhecke et al., 2014a), and pollen data (Litt et al., 2014), which were used for the construction of the agedepth model as published in Stockhecke et al. (2014a). By adding radiometric dating techniques, the Lake Van chronol- ogy was correlated by using "age control points", derived from visual synchronization with the GICC05-based NGRIP isotope data for this relevant interval $(0-116 \mathrm{ka}$; NGRIP members, 2004; Rasmussen et al., 2006; Svensson et al., 2008; Wolff et al., 2010). Additionally, a correlation with three ${ }^{40} \mathrm{Ar} /{ }^{39} \mathrm{Ar}$ dated onshore tephra layers was implemented in the age-depth model of the composite profile, i.e., the Nemrut Formation (NF) at $32.70 \pm 2.55 \mathrm{ka} \mathrm{BP}$, the Halepkalesi Pumice (HP-10) fallout at $61.60 \pm 2.55 \mathrm{ka} \mathrm{BP}$ as well as the Incekaya-Dibekli Tephra at $\sim 80 \mathrm{ka} \mathrm{BP}$ (Stockhecke et al., 2014b; Sumita and Schmincke, 2013). Within the last glacial period, the paleomagnetic Laschamp excursion at $\sim 41 \mathrm{ka} \mathrm{BP}$ (Vigliotti et al., 2014) could be identified in the core sequence. Here we want to stress that, among data sets used for visual correlation, pollen data published in Litt et al. (2014) show the glacial-interglacial changes with the largest signal amplitude. However, the age-depth model of Stockhecke et al. (2014b) is based on tuning with the NGRIP event stratigraphy. The correlation points of the Lake Van sedimentary record have been mainly defined by abiotic proxies (i.e., TOC) caused by a higher time resolution of this data set in comparison to the pollen samples available during that time. Even if we present a high-resolution pollen record in this paper, leads and lags between different biotic and abiotic proxies related to climate events have to be taken into account. 


\subsection{Palynology}

The new high-resolution palynological analyses were performed on 216 sub-samples taken at $10-20 \mathrm{~cm}$ intervals. The temporal resolution between each pollen sample, derived from the present age-depth model, ranges from $\sim 250$ years $(18.37-21.24$ mcblf-nE) to $\sim 500$ years $(3.87-$ 18.37 and 21.24-41.72 mcblf-nE; Fig. 2).

Pollen samples were processed using standard palynological techniques (Faegri and Iversen, 1993) including chemical treatment with cold $10 \% \mathrm{HCL}$, hot $10 \% \mathrm{KOH}$, cold $40 \%$ $\mathrm{HF}$, acetolysis and final sieving with $10 \mu \mathrm{m}$ mesh size. In order to calculate the pollen and micro-charcoal $(>20 \mu \mathrm{m})$ concentrations (grains cm $\mathrm{cm}^{-3}$ and particles $\mathrm{cm}^{-3}$, respectively), tablets of Lycopodium clavatum (Batch no. 483216, Batch no. 177745) were added to each sample (Stockmarr, 1971).

Pollen identification was carried out to the possible lowest taxonomic level with reference to Beug (2004), Moore et al. (1991), Punt (1976), Reille (1999, 1998, 1995), and the pollen reference collections of the SteinmannInstitute, Department of Paleobotany. Furthermore, we followed the taxonomic nomenclature after Berglund and Ralska-Jasiewiczowa (1986) and the detailed palynological investigation from western Iran (van Zeist and Bottema, 1977).

To make these pollen counts statistically representative, a minimum of $\sim 500$ identified pollen grains per sub-sample were counted for the calculation of terrestrial pollen percentages (100\%), composed of arboreal pollen (AP) and nonarboreal pollen (NAP). Spores of green algae (e.g., Pediastrum boryanum spp., $P$. simplex, $P$. kawraiskyi), dinoflagellate cysts, pollen grains of aquatic taxa and damaged pollen grains were excluded from the terrestrial pollen sum and pollen concentration. Percent calculation, cluster analysis to define pollen assemblage zones (PAZ), and construction of the pollen and charcoal diagram (Fig. 2) was carried out by using TILIA program; version 1.7.16 $\left({ }^{\odot} 1991-2011\right.$ Eric C. Grimm).

\subsection{Stable isotope analysis}

Lake Van carbonates consist of a mixture of calcite and aragonite precipitated in surface water. We selected 200 subsamples at the same stratigraphic level which was used for the pollen analysis $(20 \mathrm{~cm}$ sampling resolution). The freezedried and ground sediment samples were analyzed at the University of Kiel using a Finnigan GasBenchII with carbonate option coupled to a DELTAplusXL IRMS. The isotopic composition is given relative to the VPDB standard in the conventional $\delta$-notation and was calibrated against two international reference standards (NBS19 and NBS18). The standard deviation for reference analyses was $0.06 \%$ of the stable isotope signature.

\subsection{Profiling measurements}

Profiling measurements of the complete Lake Van sedimentary record (Ahlat Ridge site) are published and described in detail by Kwiecien et al. (2014) as well as in the high-resolution study of the last interglacial by Pickarski et al. (2015).

The sediment cores were scanned with an AVAATECH XRF Core Scanner III at MARUM (Bremen). Intensities of major elements (e.g., $\mathrm{Ca}, \mathrm{K}$ ) on sediment cores were collected every $2 \mathrm{~cm}$ down-core over a $1 \mathrm{~cm}^{2}$ area. The row XRF measurements were processed by the Iterative Least square software (WIN AXIL) package from Canberra Eurisys, providing intensity data in total counts $\left(t_{\mathrm{c}}\right)$. The $\mathrm{Ca} / \mathrm{K}$ ratio presented in this paper is unitless.

\section{Results}

\subsection{Palynology}

The palynological data of the last glacial are presented in Fig. 2. This sequence can be divided into four pollen assemblage superzones (PAS IIa, IIb, IIIa, IIIb) following the criteria described in Tzedakis (1994 and references therein), which were applied in Litt et al. (2014) for the low-resolution 600 ka long Lake Van pollen record. The PAS IIa and IIb can be further subdivided into six pollen assemblage zones (PAZ; Fig. 2) based on changes in the AP / NAP ratio and changes in the relative frequency of individual taxa. Main characteristics of each pollen zone and sub-zone as well as criteria for defining the lower boundaries are given in Table 1 .

The pollen concentration varies between $\sim 2000$ and 40000 grains $\mathrm{cm}^{-3}$ dominated by steppic herbaceous pollen types in particular by Artemisia (5-55\%), Chenopodiaceae (3-64\%), and Poaceae (6-35\%). Total arboreal pollen percentages alternate between 0.5 and $67 \%$ during the last glacial. The main tree taxa are Pinus $(0-61 \%)$ and deciduous Quercus $(0-15 \%)$, whereby the most indicative temperate taxon is deciduous Quercus characterized by relative high percentages during interstadials.

Microscopic charcoal concentrations vary between $<200$ and $\sim 15000$ particles $\mathrm{cm}^{-3}$ throughout the last glacial (Figs. 2, 3d). In general, charcoal particles of a size commonly recorded from pollen slides reflect fire on a more regional scale (e.g., Clark et al., 1998; Tinner et al., 1998). Here the Lake Van charcoal record can be divided into two distinct intervals: (I) the glacial/stadial interval, when global temperatures and terrestrial biomass were relatively low, the charcoal particles concentration stay low $(<1000$ particles $\mathrm{cm}^{-3}$ ), and (II) the early interglacial / interstadial interval, when global temperatures increased and vegetation changed, the charcoal record shows high concentrations $\left(>1000\right.$ particles $\mathrm{cm}^{-3}$ ). 

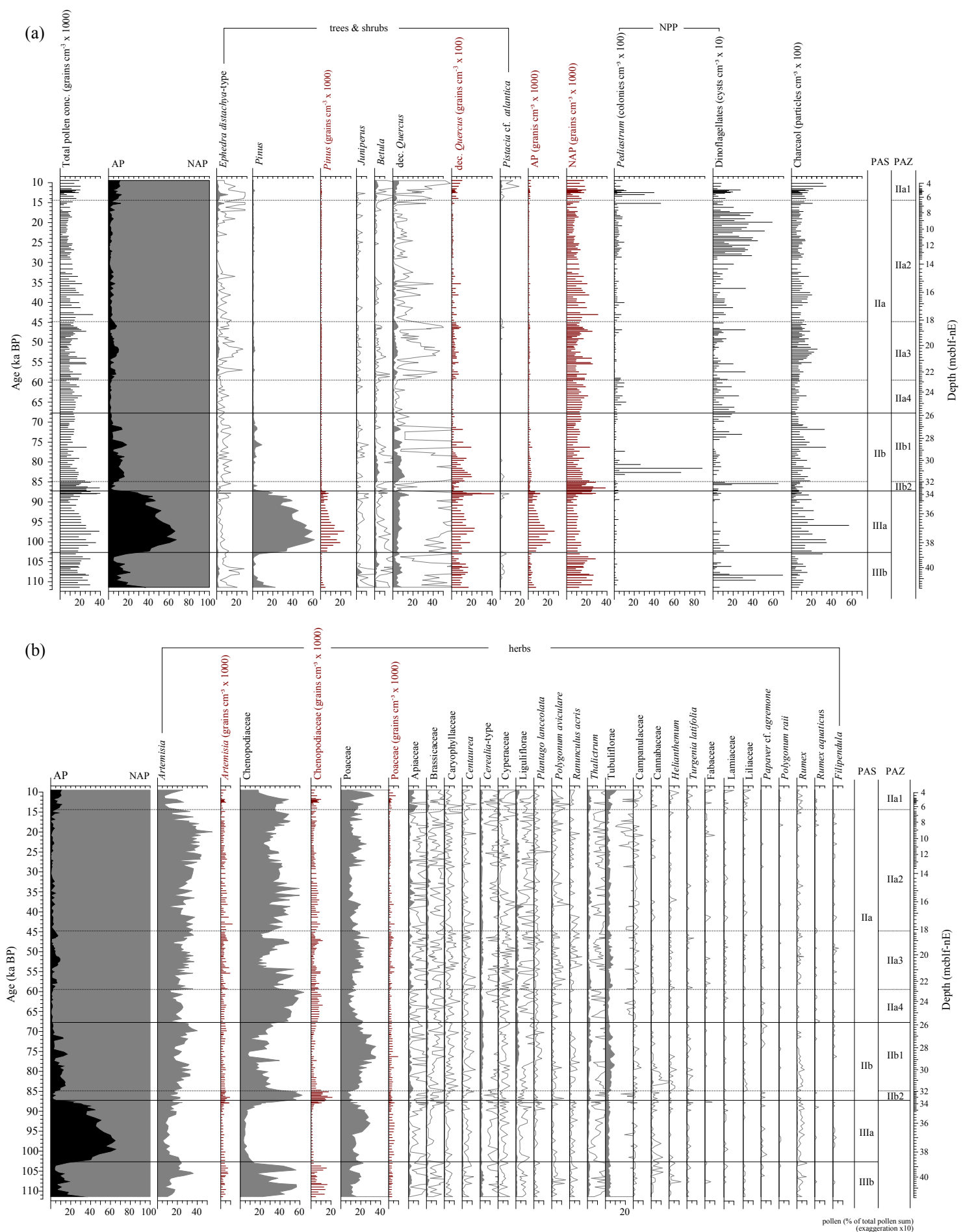

Figure 2. Pollen diagram for the analyzed last glacial period from the Ahlat Ridge composite profile plotted against age (ka BP) and depth (event-corrected composite record; mcblf-nE). A 10-fold exaggeration line (gray) is used to show changes in low percentages. PAS - Pollen assemblage superzone; PAZ - Pollen assemblage zone. For the discussion see Sect. 5. (a) Shown is an arboreal/non-arboreal ratio (AP / NAP), selected arboreal pollen percentages (AP; gray), selected arboreal pollen concentrations (grains $\mathrm{cm}^{-3}$; red bars), non-pollen palynomorph concentrations (NPP) such as Pediastrum, consisting of Pediastrum boryanum spp., P. simplex, and P. kawraiskyi (colonies $\mathrm{cm}^{-3}$; black bars), dinoflagellate concentration (cysts $\mathrm{cm}^{-3}$; black bars), and microscopic charcoal concentration ( $>20 \mu \mathrm{m}$; particles $\mathrm{cm}^{-3}$; black bars). (b) Shown is an arboreal/non-arboreal ratio (AP / NAP), selected non-arboreal pollen percentages (NAP; gray), and selected non-arboreal pollen concentrations (grains $\mathrm{cm}^{-3}$; red bars) of Artemisia, Chenopodiaceae, and Poaceae. 
Table 1. Simplified synoptic description of pollen assemblage superzones (PAS) and zones (PAZ).

\begin{tabular}{|c|c|c|c|}
\hline PAS/ PAZ & $\begin{array}{l}\text { Age } \\
(\mathrm{ka} \mathrm{BP})\end{array}$ & $\begin{array}{l}\text { Criteria for } \\
\text { lower boundary }\end{array}$ & Pollen assemblages (minimum-maximum in \%) \\
\hline IIa1 & $\begin{array}{l}09.48- \\
14.26\end{array}$ & $\begin{array}{l}\text { Occurrence of } \\
\text { Pistacia; } \\
\text { Quercus }>3 \%\end{array}$ & $\begin{array}{l}\text { Chenopodiaceae }(18-49 \%)-\text { Poaceae }(6-33 \%)-\text { Artemisia }(6-33 \%)- \\
\text { Ephedra distachya-type }(1-11 \%)-\text { dec. Quercus }(0-6 \%)-\text { Betula }(0-3 \%) \\
\text { - Pistacia cf. atlantica }(0-2 \%)-\text { Juniperus }(0-1 \%)-\text { Pinus }(0-2 \%)\end{array}$ \\
\hline $\mathrm{IIa} 2$ & $\begin{array}{l}14.26- \\
44.80\end{array}$ & Quercus $<2 \%$ & $\begin{array}{l}\text { Chenopodiaceae }(23-60 \%)-\text { Artemisia }(10-55 \%)-\text { Poaceae }(7-26 \%)- \\
\text { Ephedra distachya-type }(0-7 \%)-\text { dec. Quercus }(0-4 \%)-\text { Pinus }(0-2 \%)- \\
\text { Betula }(0-1 \%)\end{array}$ \\
\hline IIa3 & $\begin{array}{l}44.80- \\
59.50\end{array}$ & $\begin{array}{l}\text { Quercus } \\
>2 \% \\
\text { Chenopodiaceae } \\
<50 \%\end{array}$ & $\begin{array}{l}\text { Chenopodiaceae }(15-57 \%) \text { - Artemisia }(12-37 \%) \text { - Poaceae }(10-28 \%)-\text { dec. } \\
\text { Quercus }(0-5 \%)-\text { Ephedra distachya-type }(0-3 \%)-\text { Betula }(0-2 \%)-\text { Cyper- } \\
\text { aceae }(0-2 \%)-\text { Pinus }(0-2 \%)\end{array}$ \\
\hline $\mathrm{IIa} 4$ & $\begin{array}{l}59.50- \\
67.72\end{array}$ & $\begin{array}{l}\text { Chenopodiaceae } \\
>50 \%\end{array}$ & $\begin{array}{l}\text { Chenopodiaceae }(29-64 \%)-\text { Artemisia }(12-31 \%)-\text { Poaceae }(6-22 \%)-\text { Betula } \\
(0-1 \%)-\text { Ephedra distachya-type }(0-1 \%)-\text { Pinus }(0-1 \%)-\text { dec. Quercus }(0- \\
1 \%)\end{array}$ \\
\hline IIb1 & $\begin{array}{l}67.72- \\
84.91\end{array}$ & $\begin{array}{l}\text { Quercus } \\
>5 \% \\
\text { Chenopodiaceae } \\
<50 \%\end{array}$ & $\begin{array}{l}\text { Artemisia }(16-40 \%)-\text { Chenopodiaceae }(8-57 \%)-\text { Poaceae }(7-35 \%)-\text { dec. } \\
\text { Quercus }(0-12 \%)-\text { Pinus }(0-9 \%)-\text { Betula }(0-5 \%)-\text { Ephedra distachya-type } \\
(0-2 \%)-\text { Juniperus }(0-1 \%)\end{array}$ \\
\hline IIb2 & $\begin{array}{l}84.91- \\
87.24\end{array}$ & $\begin{array}{l}\text { Pinus }<20 \% \\
\text { Chenopodiaceae } \\
>50 \%\end{array}$ & $\begin{array}{l}\text { Chenopodiaceae }(44-62 \%)-\text { Artemisia }(11-23 \%) \text { - Poaceae }(7-12 \%)-\text { Pinus } \\
(0-16 \%) \text { - dec. Quercus }(0-4 \%)-\text { Betula }(0-1 \%)-\text { Ephedra distachya-type } \\
(0-1 \%)\end{array}$ \\
\hline IIIa & $\begin{array}{l}87.24- \\
102.67\end{array}$ & $\begin{array}{l}\text { Pinus }>20 \% \\
\text { Chenopodiaceae } \\
<20 \%\end{array}$ & $\begin{array}{l}\text { Pinus }(7-61 \%) \text { - Poaceae }(8-29 \%)-\text { Artemisia }(5-25 \%)-\text { Chenopodiaceae } \\
(3-50 \%)-\text { dec. Quercus }(3-15 \%)-\text { Betula }(0-2 \%)-\text { Alnus }(0-1 \%)-\text { Ephedra } \\
\text { distachya-type }(0-1 \%)-\text { Juniperus }(0-1 \%)-\text { Pistacia } \text { cf. atlantica }(0-1 \%)\end{array}$ \\
\hline IIIb & $\begin{array}{l}102.67- \\
111.70\end{array}$ & $\begin{array}{l}\text { Chenopodiaceae } \\
>20 \%\end{array}$ & $\begin{array}{l}\text { Chenopodiaceae }(14-57 \%)-\text { Poaceae }(8-22 \%)-\text { Artemisia }(7-36 \%)-\text { dec. } \\
\text { Quercus }(1-9 \%)-\text { Pinus }(0-22 \%)-\text { Juniperus }(0-5 \%)-\text { Betula }(0-4 \%)- \\
\text { Ephedra distachya-type }(0-3 \%)-\text { Fraxinus }(0-1 \%)-\text { Pistacia cf. atlantica } \\
(0-1 \%)\end{array}$ \\
\hline
\end{tabular}

\section{$4.2 \delta^{18} \mathrm{O}_{\text {bulk }}$ and XRF}

The oxygen isotopic composition of bulk sediments $\left(\delta^{18} \mathrm{O}_{\text {bulk }}\right)$ reflects regional climate changes and local temperature variability. However, the interpretation of $\delta^{18} \mathrm{O}_{\text {bulk }}$ is complex as it can be influenced by a number of climate variables, such as air and water temperature, seasonality of precipitation, moisture source and precipitation-to-evaporation ratio. According to Litt et al. $(2012,2009)$ and Lemcke and Sturm (1997), the $\delta^{18} \mathrm{O}_{\text {bulk }}$ values of carbonates at Lake Van are primarily controlled by evaporation processes. Furthermore, Kwiecien et al. (2014) and Pickarski et al. (2015) mention that changes in seasonal rainfall have a significant effect on lake water isotope values. During the last glacial, the oxygen isotope signature of carbonates was apparently heavier during interstadials and lighter during stadials (Fig. 3b).
The presented $\mathrm{Ca} / \mathrm{K}$ record displays a ratio between authigenic carbonate precipitation and siliciclastic material input from the drainage (Kwiecien et al., 2014). According to Kwiecien et al. (2014), the $\mathrm{Ca} / \mathrm{K}$ ratio shows higher values ascribed to higher amounts of authigenic carbonate during warmer periods (interstadials / interglacial) and lower values related to increasing detrital input during stadials/glacial (Fig. 3c).

\section{Discussion}

\subsection{Long-term vegetation dynamics at Lake Van}

Variations in the orbital configuration of the Earth are responsible for changes in the climate system from one state to another; on millennial timescales, for glacial-interglacial cy- 


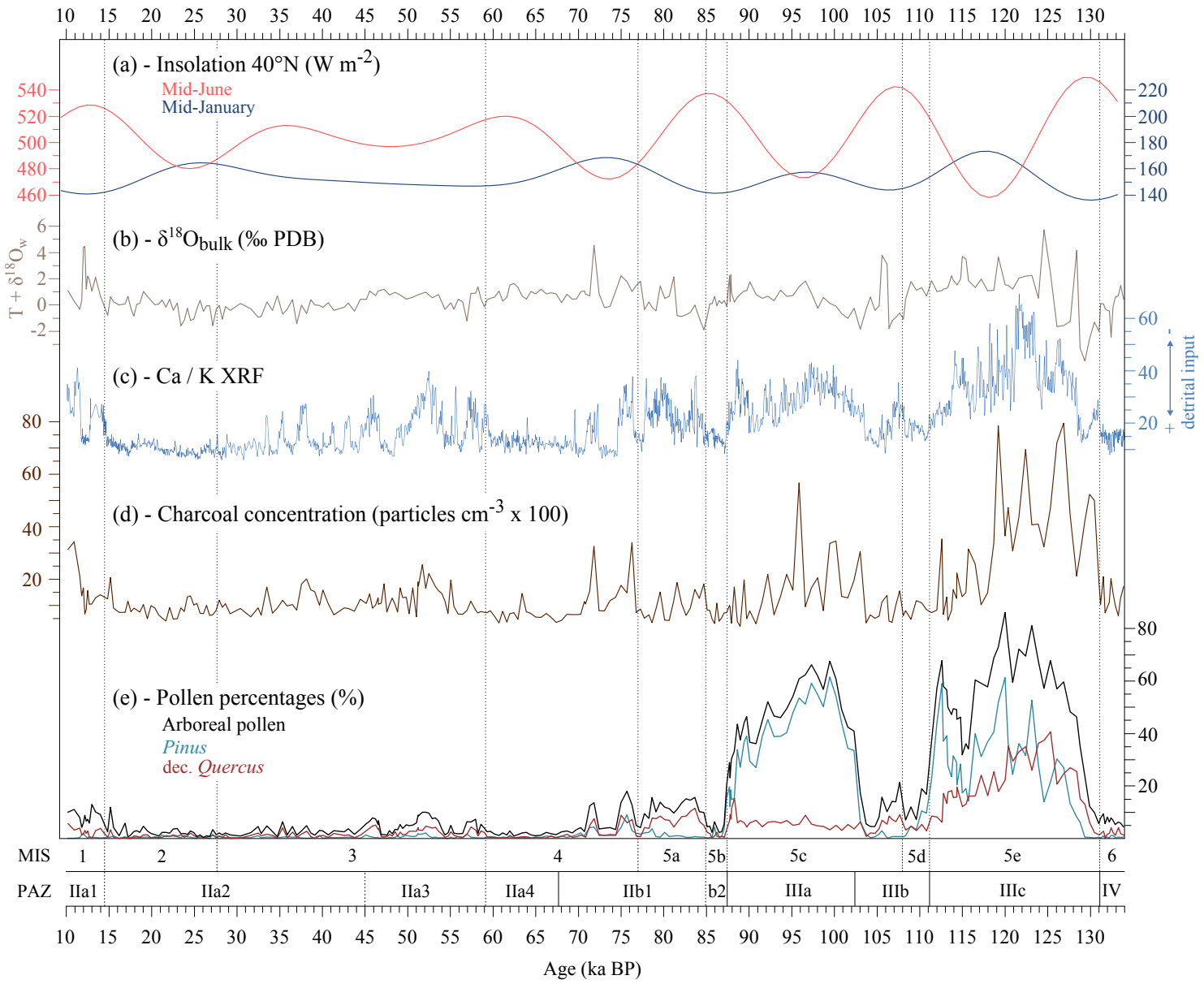

Figure 3. Comparative study of the Lake Van paleoenvironmental sequence encompassing the last glacial-interglacial cycle. (a) MidJune and Mid-January insolation at $40^{\circ} \mathrm{N}\left(\mathrm{W} \mathrm{m}^{-2}\right.$; Berger, 1978; Berger et al., 2007); (b) Lake Van oxygen isotope record $\left(\delta^{18} \mathrm{O}_{\text {bulk }}\right.$ in $\%$ PDB) of autochthonous precipitated carbonates. Shown is the temperature $(T)$ and the isotopic composition $\left(\delta^{18} \mathrm{O}_{\mathrm{w}}\right)$ of the epilimnion; (c) calcium/potassium ratio (Ca / K) after Kwiecien et al. (2014); (d) microscopic charcoal concentration (particles $\mathrm{cm}^{-3}$ ) from 10-110 ka BP (this study) and from 110-135 ka BP (MIS 5e; Pickarski et al. 2015); (e) selected Lake Van arboreal pollen percentages (AP, Pinus, deciduous Quercus) from 10 and $110 \mathrm{ka} \mathrm{BP}$ (this study) and from 110-135 ka BP described in Pickarski et al. (2015). MIS - Marine Isotope Stage; PAZ - Pollen assemblage zone.

cles (Berger, 1978; Berger et al., 2007). However, higher frequency oscillations (e.g., Dansgaard-Oeschger events; Dansgaard et al., 1993) are superimposed on the long-term orbitally driven climate dynamics. These abrupt changes of the climate system are not directly driven by orbital forcing, but can be interpreted as transitions between two states of the inter-hemispheric Atlantic Ocean circulation driven by largescale thermal and salinity gradients (e.g., Bond and Lotti, 1995; Cacho et al., 2000, 1999; Chapman and Shackleton, 1999; Hemming, 2004; Hodell et al., 2008; McManus et al., 1999; Rasmussen et al., 2014; Wolff et al., 2010). In particular, changes in the oceanic circulation affected regional and local atmospheric circulation patterns, for example, the strength and position of the westerlies in the Northern Hemisphere, which are responsible for the moisture supply in east- ern Anatolia (Akçar and Schlüchter, 2005; Roberts et al., 2008).

According to Jessen and Milthers (1928) and Litt et al. (2014), an interstadial stage is an interval of temporary improved climate within a glacial phase, which has been either too short to permit full expansion of thermophilous trees and/or too cold or dry to reach the climate optimum of an interglacial period in the same region. In comparison, stadial stages correspond to cold / dry intervals marked not only by global but also by local ice re-advances (Lowe and Walker, 1984).

Below, we will discuss only the most pronounced interstadials (e.g., MIS 5c and 5a) and Dansgaard-Oeschger interstadials (AP > 10\%; e.g., DO 19, 17-16, 14, 12, 8 and 1), here identified on the basis of the Lake Van pollen record (see also Litt et al., 2014). All other "warm / wet" phases with lower 
expansion of temperate trees ( $\mathrm{AP}<10 \%$ ) are not explicitly mentioned in the following section.

\section{MIS 5e-5a}

The last interglacial at Lake Van (MIS 5e; 131.2$111.5 \mathrm{kaBP}$; Pickarski et al., 2015) is characterized by an oak steppe-forest during the climate optimum (129.1$124.1 \mathrm{kaBP}$ ), while coniferous species (e.g., Pinus) dominated the late interglacial period between 124.1 and $111.5 \mathrm{kaBP}$ at the minimum peak in summer insolation (Pickarski et al., 2015; Fig. 3a, e). The expansion of drytolerant and/or cold-adapted Pinus (probably Pinus nigra) going along with a reduction of warm-temperate species (e.g., deciduous oak) demonstrates cooler temperatures and summer-dry conditions during the late interglacial period (Pickarski et al., 2015). In this regard, Litt et al. (2014) argued that positive summer temperature anomalies and negative winter temperature anomalies during the late interglacial lead to a strong continentality, more precisely, to strong temperature variations with still low moisture availability in eastern Anatolia.

MIS $5 \mathrm{~d}$ is marked by a significant expansion of steppic herbaceous plants at the expense of wooded landscape, which signals a considerable climate deterioration from $\sim 111.5$ 107.8 ka BP (Herning stadial; AP < 20\%; Fig. 3e). The regional climate at Lake Van was characterized by a strong seasonal moisture deficiency $\left(\delta^{18} \mathrm{O}_{\text {bulk }}\right.$ values $>2 \%$, Fig. $\left.3 \mathrm{~b}\right)$. Cold and/or dry climatic conditions with marked seasonality in precipitation during the stadial were responsible for poor soil development and enhanced erosion of regional material as recorded by the $\mathrm{Ca} / \mathrm{K}$ ratio (Fig. 3c).

An abrupt shift in most proxies (pollen data, $\delta^{18} \mathrm{O}_{\text {bulk }}$, $\mathrm{Ca} / \mathrm{K}$ ratio) displays the onset of two pronounced interstadials at 107.8-87.2 kaBP (Brørup interstadial; MIS 5c) and at $84.9-77.5 \mathrm{kaBP}$ (Odderade interstadial; MIS 5a; Fig. 3). The rapid decrease in steppic herbaceous elements (e.g., Chenopodiaceae) and the slow increase of summer-green oaks suggest that climate in eastern Anatolia became progressively warmer and wetter during these interstadials. Similar to the late interglacial stage (124.1111.5 ka BP; Pickarski et al., 2015), the Brørup interstadial recorded a slight climatic amelioration that continued with the predominance of cold- and/or summer-dry adapted conifers (Pinus $>60 \%$, Fig. 3e; Pinus concentration $>20000$ grains $\mathrm{cm}^{-3}$, Fig. 2). Changes in seasonal rainfall inferred from depleted $\delta^{18} \mathrm{O}_{\text {bulk values (up to }-2 \% \text { ) to more }}$ positive oxygen isotope signatures $(>1 \%$ ) and generally lower winter temperatures have a decisive negative impact on moisture-requiring thermophilous plants such as deciduous oaks $(<10 \%$, Table 1 ; Fig. 3e). Therefore, the likely occurrence of deciduous Quercus in higher altitudes, for instance at southern slopes of the Bitlis Massif, would be caused by increasing orography-related precipitation amounts (Litt et al., 2014). An open oak steppe-forest, which was predomi- nant during the MIS 5e at Lake Van, did not become dominant at any time during the last glacial (Fig. 3e; Pickarski et al., 2015).

The new high-resolution microscopic charcoal data show that fire frequency had an immediate response to climate variability (Fig. 3d). According to previous high-resolution pollen studies by Wick at al. (2003) and Pickarski et al. (2015), rising global temperature and increased moisture availability leads to higher vegetation productivity (e.g., higher vegetation density due to the spread of warmtemperate grasslands) that correlates to considerably more fuel for burning during interstadials ( $>1000$ charcoal particles $\mathrm{cm}^{-3}$; Fig. 3d). During stadials, lower microscopic charcoal concentrations (between 300 and 850 particles $\mathrm{cm}^{-3}$ ) characterizes an open dry desert-steppe landscape with low vegetation density (e.g., MIS 5b; Daniau et al., 2010; Sadori et al., 2015; Vanniere et al., 2011; Fig. 3d).

After a short-term climatic deterioration between $\sim 87.3$ to $84.9 \mathrm{ka}$ BP (MIS 5b; Rederstall stadial, AP $<10 \%$ ) characterized by a similar expansion of steppic herbaceous plants as documented for MIS 5d (Herning stadial), the spread of deciduous oaks defined the beginning of the MIS 5a. Environmental conditions of the Odderade interstadial (MIS 5a; $\sim 85-77 \mathrm{ka} \mathrm{BP}$ ) are difficult to resolve due to the eruption of the Incekaya-Dibekli volcano at $\sim 80 \mathrm{kaBP}$ (Sumita and Schmincke, 2013). The fragmentary documentation of the vegetation signal, primarily due to the respective admixture of pyroclastic material (Stockhecke et al., 2014b), complicates the study of vegetation and climate evolution at Lake Van. Nevertheless, the briefly rising AP level (AP > 10\%) consisting of deciduous Quercus, Betula and the sporadic occurrence of Pistacia cf. atlantica, points to short-term favorable climatic conditions and an increased moisture availability at the beginning of MIS 5a (Figs. 2, 3e). Relatively high fire intensity (charcoal concentration up to 2000 particles $\mathrm{cm}^{-3}$; Fig. 3d) and lower detrital input (Fig. 3c) support an advancing vegetation cover due to warmer climatic conditions. However, Pinus, which was dominant during MIS $5 \mathrm{e}$ and MIS 5c, is no longer growing in the vicinity of the lake (less than $4 \%$; Pinus concentration $<200$ grains cm $^{-3}$, Figs. 2, 3e). The shift from depleted oxygen isotope signature $(-1.90 \%$ o $)$ to more positive values $(1.81 \%$, Fig. $3 \mathrm{~b})$ confirms the reduction in precipitation and/or increasing evaporation throughout the MIS 5a.

\subsection{Abrupt climate changes during MIS 4-2}

The general dominance of Artemisia, Chenopodiaceae, Poaceae and the decrease of arboreal pollen (AP $<10 \%$; mainly deciduous Quercus and Pinus) in the glacial pollen spectra indicate a wide spread of arid desert-steppe vegetation in eastern Anatolia between $\sim 75-12$ ka BP (Figs. 2, 3 ). However, the total absence of moisture-requiring thermophilous arboreal species such as Ulmus and Carpinus betulus or frost-sensitive taxa (e.g., Pistacia cf. atlantica, 
evergreen Quercus), a low vegetation density, a high terrigenous input (of fluvial and/or eolian origin; Fig. 3c), a consistently positive $\delta^{18} \mathrm{O}_{\text {bulk }}$ signature $(\sim 0.77 \%$; Fig. $3 \mathrm{~b})$, and a decreasing microscopic charcoal concentration (from $\sim 1700$ to $<400$ particles $\mathrm{cm}^{-3}$; Fig. 3d) point to a strong aridification and cooling in eastern Anatolia after $70 \mathrm{kaBP}$. The observation is consistent with low summer insolation (Berger, 1978; Berger et al., 2007), increased global ice volume (Shackleton, 1987), and cooler sea surface temperature (SST; Cacho et al., 2000), which, combined with the atmospheric effects of a weakening AMOC (Atlantic Meridional Overturning Circulation; Böhm et al., 2015; Bond et al., 1993) contributed to a widespread aridity across the Mediterranean region (e.g., Fletcher et al., 2010; Kwiecien et al., 2009; Sánchez Goñi et al., 2002).

During MIS 4 to 2, high-frequency vegetation and environmental oscillations in the Lake Van proxies demonstrate a reproducible pattern of centennial to millennial-scale alternation between DO interstadials and DO stadials (Fig. 4; Dansgaard et al., 1993; NGRIP members, 2004; Rasmussen et al., 2014; Sánchez Goñi and Harrison, 2010; Svensson et al., 2006; Wolff et al., 2010). In comparison with the Greenland isotope curve, intervals with lighter $\delta^{18} \mathrm{O}$ NGRIP values (DO stadials; Fig. 4a) coincide with lower percentages of AP at Lake Van (Fig. 4b). An increase in deciduous Quercus percentages, which is an important criterion for initial warming intervals during Termination 1 (Litt et al., 2014, 2009; Wick et al., 2003) and Termination 2 (Pickarski et al., 2015), is characteristic for each DO interstadial (Fig. 3e).

In general, the abrupt variability of temperate AP from Lake Van and $\delta^{18} \mathrm{O}$ NGRIP values are more or less synchronous (Fig. 4). Leads and lags between the proxy records, illustrated in detail in Fig. 5, are difficult to assess due to their heterogeneous resolution. In any case, we cannot expect a perfect matching between biotic and abiotic proxies related to climate events due to their different response time. In addition, the lack of correspondence between the pollen signal and the timing of some DO events could also be explained by uncertainties in the current age-depth model (see Stockhecke et al., 2014a). Still, as expected from various eastern Mediterranean pollen records, the Lake Van pollen record documents that temperate taxa tend to reach their maxima after the onset of a warming phase and, therefore, lag behind the $\mathrm{Ca} / \mathrm{K}$ increase, which responds immediately to climate changes (Fig. 5).

The longest and most pronounced variability of tree populations in the Lake Van pollen record is shown during the MIS $3(\sim 61-28 \mathrm{kaBP})$, suggesting a rapid alternation of warmer/wetter interstadials and cooler/drier stadials. High-amplitude variations in the $\mathrm{Ca} / \mathrm{K}$ ratio of Lake Van sediments indicate changes in erosion of regional material, due to unstable environmental conditions in the catchment area. Larger interstadials such as DO 19, 17-16, 14, 12, and 8 are indicated by peaks in the $\mathrm{Ca} / \mathrm{K}$ ratio, which are concurrent with AP maxima and increased regional fire frequency
(Fig. 5). As described above, this millennial-scale variability in the proxy record was indirectly modulated by orbitaldriven changes and variations in the atmospheric circulation of the Northern Hemisphere (e.g., Cacho et al., 2000, 1999; Chapman and Shackleton, 1999; Hemming, 2004; Hodell et al., 2008; McManus et al., 1999; Rasmussen et al., 2014; Wolff et al., 2010). Consequently, the vegetation and environmental conditions at Lake Van respond to abrupt shifts in temperature and moisture availability related to the position and strength of the westerlies, which brought mild and humid conditions from the North Atlantic into the eastern Mediterranean region (Akçar and Schlüchter, 2005; Allen et al., 1999; Fletcher et al., 2010; Müller et al., 2011; Roberts et al., 2008). The Lake Van $\delta^{18} \mathrm{O}_{\text {bulk }}$ signature supports the suggestion of favorable environment by the receipt of isotopically depleted meltwater supply and/or increased precipitation between $\sim 57$ and $54 \mathrm{ka} \mathrm{BP}\left(\delta^{18} \mathrm{O}_{\text {bulk }}\right.$ from $-1.21 \mathrm{up}$ to $\sim 1 \%$; Fig. $3 b$ ). Furthermore, we propose that the interval of constantly heavier $\delta^{18} \mathrm{O}_{\text {bulk }}$ values during DO 14 to 12 reflect higher evaporation at Lake Van.

The most pronounced DO stadials, i.e., the stadials preceding DO 17, 12, 8, 4, and DO 1 refer to Heinrich events (HE) 6, HE 5, HE 4, HE 3, and HE 1 (Fig., 4a; Bond and Lotti, 1995; Bond et al., 1993; Heinrich, 1988). The reduction of oceanic heat transport (weakening or shut down of the AMOC; Böhm et al., 2014; Bond and Lotti, 1995; Bond et al., 1993; Broecker, 1994; Cacho et al., 2000, 1999; Chapman and Shackleton, 1999) led to significantly cooler Mediterranean SST's and climatic conditions in the Mediterranean region (e.g., Allen et al., 1999; Fletcher et al., 2010; Müller et al., 2011; Sánchez Goñi et al., 2002; Tzedakis, 2005; Tzedakis et al., 2004). According to Kwiecien et al. (2009), a decreasing atmosphere-sea-surface thermal gradient of the Mediterranean Sea would have caused a reduction in the frequency and strength of storm tracks, which were responsible for an intensifying aridity in the eastern Mediterranean region. However, since tree populations were already limited at Lake Van during the last glacial $(<10 \% \mathrm{AP})$, the pollen signal is relatively insensitive to severe climatic deterioration such as Heinrich events. Hence, both types of stadials, Heinrich events and DO stadials, lead to a similar reduction of tree taxa (mainly deciduous Quercus), and therefore cannot be clearly distinguished from an average cooling event (Fig. 4b). An exception might be the HE 5 ( $\sim 49$ ka BP; Fig. 4a). A collapse of AP taxa from $10 \%$ to less than $2 \%$ (Fig. $4 \mathrm{~b}$ ) and a short-term detrital supply (Fig. 3c) show that the climate of HE 5 was as cold and dry as the glacial maximum of MIS 4 between 70 and $60 \mathrm{ka} \mathrm{BP}$.

Between $\sim 28$ and $14 \mathrm{kaBP}$ (MIS 2), very low AP percentages $(<10 \%$; Fig. $3 \mathrm{e})$ and a decreasing fire frequency (Fig. 3d) without significant fluctuations underline considerably stable climate conditions but pronounced regional cooling and aridity in comparison to MIS 3. It led to an overall reduction in terrestrial biomass production and thus to a decrease in fuel availability for burning in the catchment 


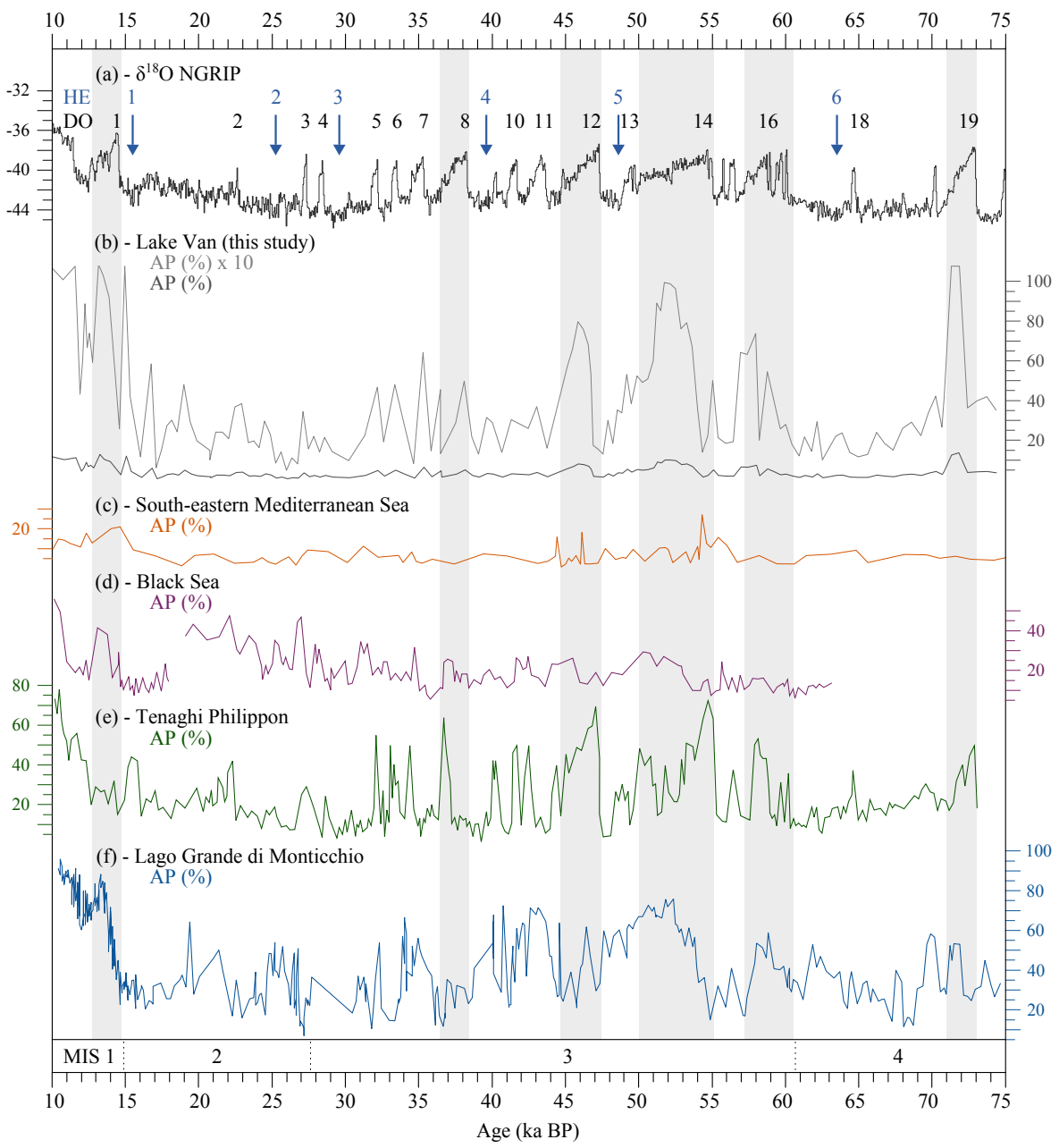

Figure 4. Regional comparison of vegetation dynamics and climate variability in the central and eastern Mediterranean area and Black Sea region concerning Dansgaard-Oeschger cycles (DO) and Heinrich events (HE). The gray bars represent the most pronounced DO interstadials DO 19, 17-16, 14, 12, 8, and DO 1, which are discussed in Sect. 5.2. (a) $\delta^{18}$ O-profile from NGRIP ice core, Greenland (NGRIP members, 2004), labeled with DO 1 to 19 and HE 1 to HE 6 (Bond et al., 1993); (b) Lake Van arboreal pollen record (AP in \%, black line) with 10fold exaggeration (gray line); (c) marine arboreal pollen record (Core 9509) obtained from the south-eastern Levantine Basin (south-eastern Mediterranean Sea; Langgut et al., 2011); (d) AP record from the SE Black Sea (core 22-GC3 for the period from 10 to $18 \mathrm{ka}$ BP after Shumilovskikh et al. (2012) and core 25-GC1 for the sequence between 19 and $63 \mathrm{ka} \mathrm{BP}$ (Shumilovskikh et al., 2014); (e) arboreal pollen record from Tenaghi Philippon, Greece (Müller et al., 2011); (f) AP record from Lago Grande di Monticchio, southern Italy (Allen et al., 1999). MIS - Marine Isotope Stage.

area. Furthermore, the presence of Juniperus, indicative for an unstable soil cover, enhanced minerogenic input into the lake (low Ca / K; Fig. 3c) and a drop in $\delta^{18} \mathrm{O}_{\text {bulk }}$ values (up to $-1.6 \%$; Fig. $3 \mathrm{~b}$ ) support the assumption of wide open plains around Lake Van. Insolation changes became the major driver (e.g., low summer insolation, Fig. 3a) and leads to a cooling of global climatic conditions, which results in a maximum ice extent of the Northern Hemisphere during the last glacial maximum (LGM; Cacho et al, 2000, 1999; Chapman and Shackleton, 1999; NGRIP members, 2004; Rasmussen et al., 2014; Sánchez Goñi and Harrison, 2010; Wolff et al., 2010).
After the LGM (at $21 \pm 2 \mathrm{ka}$; Tzedakis, 2007 and references therein), high summer insolation (Fig. 3a), decreasing global ice volume (Wolff et al., 2010), the resumption of the westerly activity, enhanced precipitation (depleted $\delta^{18} \mathrm{O}_{\text {bulk }}$ values; Fig. 3b), and locally rising temperatures in eastern Anatolia promoted an expansion of an oak steppe-forest at Lake Van (DO 1 at $\sim 14 \mathrm{kaBP}$; synonymous with the Bølling-Allerød warm period; Figs. 3e, 4). However, the Late Glacial-Holocene transition (Termination I) was interrupted by the impact of the Younger Dryas (YD) climate reversal between $\sim 12.8-11.6 \mathrm{kaBP}$ (Litt et al., 2009; Wick et al., 2003). This dramatic event is characterized by the $\delta^{18} \mathrm{O}_{\text {bulk }}$ peak (4.46\%; Fig. 3b), by the drop of the charcoal concen- 

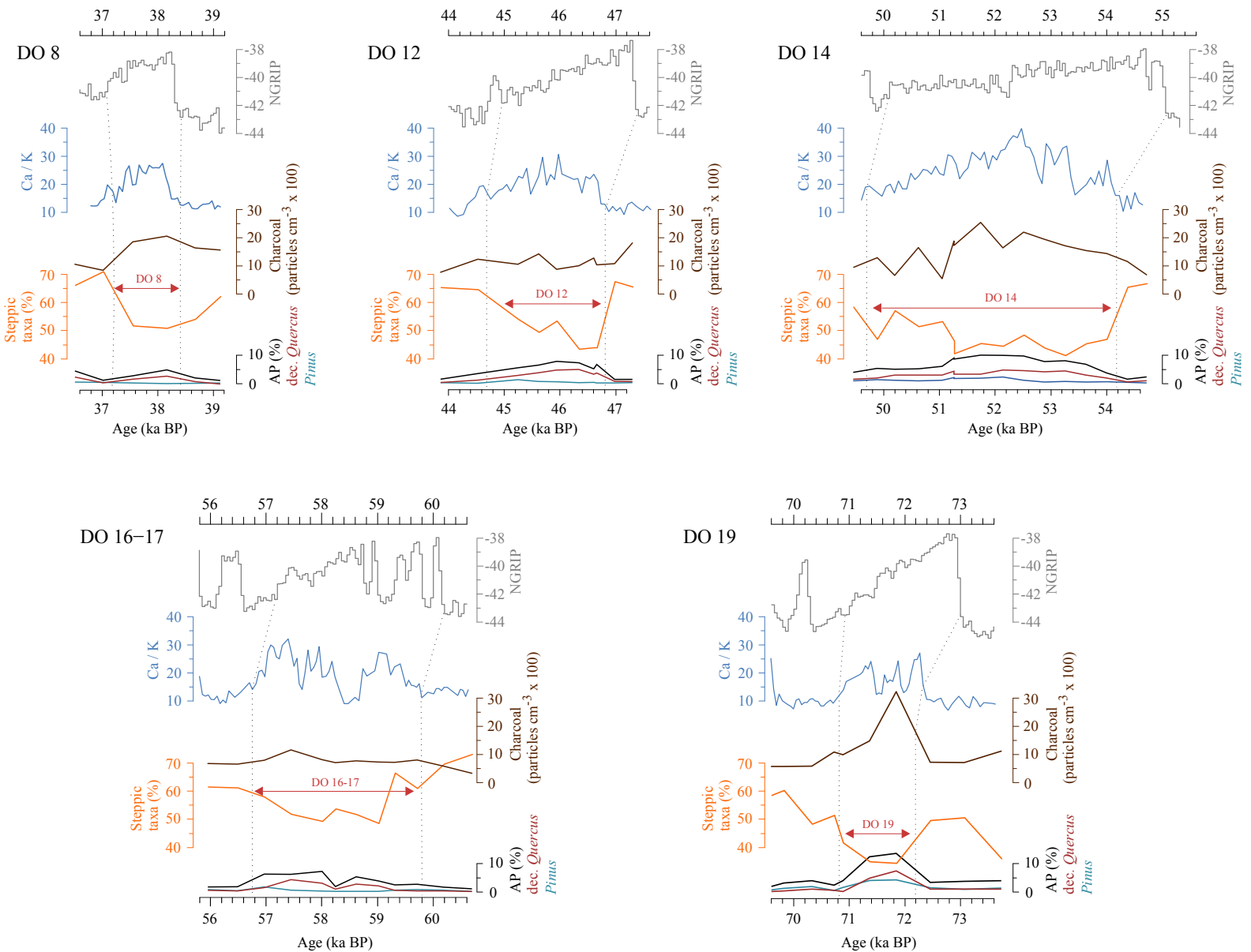

Figure 5. The most pronounced Dansgaard-Oeschger events DO 8, DO 12, DO 14, DO 16-17 and DO 19 are plotted in extra graphs, demonstrating a good correlation between the vegetation and environmental dynamics in eastern Anatolia and the $\delta^{18} \mathrm{O}$-profile from the Greenland ice core sequence (NGRIP members, 2004); Ca / K ratio after Kwiecien et al. (2014); microscopic charcoal concentration (particles $\mathrm{cm}^{-3}$, this study); selected Lake Van arboreal pollen (AP, Pinus, deciduous Quercus in \%, this study). The term "Steppic taxa" includes only major dry-adapted plants such as Chenopodiaceae and Artemisia.

tration $\left(<1000\right.$ particles $\mathrm{cm}^{-3}$; Fig. 3d), and by the rapid increase of arid desert-steppe plants (up to $70 \%$; Fig. 2b). Further details about the Late Glacial and early Holocene pollen and microscopic charcoal record of Lake Van are not considered here, as Litt et al. (2009) and Wick et al. (2003) already presented vegetation and inferred environmental conditions for that period.

\subsection{Comparison with palynological records from the Mediterranean and Black Sea region}

A regional comparison between Lake Van and pollen archives from the central (Lago Grande di Monticchio, Italy; Allen et al., 1999) and the eastern Mediterranean regions (Tenaghi Philippon, Greece; Müller et al., 2011), the southeastern Levantine Basin (Core 9509; Langgut et al., 2011), and the Black Sea (Shumilovskikh et al., 2014, 2012) is presented in Fig. 4. Despite differences in elevation, topography and chronology, the paleoenvironmental investigation indicates a good match based on the similar main trends of the major vegetation elements between the five pollen records. It should be noted that the Lago Grande di Monticchio sequence features an independent chronology based on varve counting. Climatic teleconnections between the North Atlantic, Black Sea and different parts of the Mediterranean region are expressed by coeval minima in AP during stadials, suggesting cold and dry conditions and a rather open landscape, in particular during MIS 4 and MIS 2. Between 60 and $45 \mathrm{ka} \mathrm{BP}$, the pollen record from Lake Van reveals a period of increased tree vegetation, which are interpreted as the signature of enhanced precipitation and higher temperature (DO 17-16, 14, and 12; Fig. 4b, gray bars). According to Müller et al. (2011), this period was described as the North African Humid Period (NAHP; ca. 55-49 ka BP), where the anatomically modern humans (AMH) migrated from Africa via the Levant to Europe. During that time, climatic conditions in 
the eastern Mediterranean were more humid and milder as indicated by an abrupt shift from desert-steppe vegetation to semi-arid grassland at Lake Van (AP $\sim 10 \%$; Fig. $4 b$ ) and to open forest vegetation (AP up to $70 \%$, Fig. 4e) in the Tenaghi Philippon area (Müller et al., 2011). The marine pollen record from the south-eastern Levantine Basin (Fig. 4c) also points to increasing AP percentages during $\sim 56.0$ and $44.5 \mathrm{ka} \mathrm{BP}$ (Langgut et al., 2011).

However, there are some differences between the pollen records. More developed forests exist around the central and eastern Mediterranean Sea and the Black Sea compared to the Near East. Despite the intensive aridification in eastern Anatolia during glacial, the vegetation composition of Lake Van and the Levantine Basin differs from the terrestrial Mediterranean pollen records. Firstly, drought-sensitive taxa such as Ulmus, Carpinus betulus and Fagus were frequently present in Italy, e.g., at Lago Grande di Monticchio, Valle di Castiglione, Stracciacappa and Lagaccione (Allen et al., 1999; Follieri et al., 1998) even during stadials. Secondly, the high-resolution Tenaghi Philippon and Ioannina sequences (Müller et al., 2011; Tzedakis et al., 2002) show that thermophilous trees (e.g., deciduous Quercus) increased rapidly during each interstadial without migrational lags (Fig. 4e). It suggests that these sites were better suited in sustaining refugial temperate tree population due to the effects of orographic precipitation (e.g., Müller et al., 2011; Tzedakis et al., 2002). Thirdly, both the diversity and the low amplitude of variations in temperate tree taxa of the eastern Mediterranean pollen records (Lake Van and Levantine Basin; Fig. 4b, c) indicates greater distances and/or slow migration rates from refugia during the glacial interval. Such areas might be found in the south and south-east Black Sea Mountains (Euxinian vegetation) and the Caucasus mountains (Hyrcanian vegetation), which receive increased atmospheric moisture and higher orographic precipitation from the Black Sea (Bottema, 1986; Leroy and Arpe, 2007; Shumilovskikh et al., 2012). Especially the Black Sea region was characterized by mean winter temperatures close to or above $0{ }^{\circ} \mathrm{C}$ during the last glacial (Shumilovskikh et al., 2014).

Moreover, the different vegetation development in the Mediterranean region demonstrates a west to east vegetation gradient from an open temperate forest (including evergreen species) in the central (Allen et al., 1999; Follieri et al., 1998) and eastern Mediterranean (Müller et al., 2011) to a semiarid grassland in the Near East during DO interstadials. In eastern Anatolia, the availability of precipitation is the limiting factor for the establishment of an open oak steppe-forest. This moisture gradient reflects an increasing continental affect and a decreasing influence of changes in the atmospheric circulation of the Northern Hemisphere.

\section{Conclusions}

1. By using a range of paleoenvironmental proxies, we were able to detect subtle climate changes even during generally cold and arid glacial phases. This study illustrates the great potential of Lake Van as an archive of eastern Mediterranean climate and environment over the entire Quaternary.

2. Our new palynological results show the climatic teleconnection between Lake Van and the Atlantic Ocean. It reflects the complex underlying drivers of high frequency regional climate and environmental variability caused by seasonal insolation changes, ice sheet dynamics, and the ocean circulation in the North Atlantic.

3. The comparison with central and eastern Mediterranean and Black Sea pollen sequences reveals a west to east gradient of decreasing moisture in the Mediterranean region due to an increasing continental effect and a reduction of the atmospheric impact of the North Atlantic Ocean.

4. Dansgaard-Oeschger cycles are clearly recognized in the Lake Van pollen record and by other abiotic proxies. Interstadials are characterized by the spread of temperate vegetation (e.g., deciduous Quercus) suggesting regional moisture availability. Stadials can be recognized by the dominance of steppe elements (e.g., Artemisia, Chenopodiaceae) pointing to cold temperature and an increasing aridity.

5. Heinrich events cannot clearly be distinguished from an average cooling event (stadials). They show a similar impact on the vegetation and the environment.

6. The supply of detrital material seems to respond directly to changes in the vegetation composition, e.g., the terrestrial supply is low (high authigenic carbonate precipitation) when the vegetation cover in the catchment area is dense. In contrast, an open landscape favors a physical erosion including local detrital and dust input.

7. Moreover, the fire frequency at Lake Van indicates an immediate link to climate changes. The fire frequency is high when global temperatures and regional moisture levels increase providing a higher terrestrial biomass production.

\section{Data availability}

The complete pollen data set is available on the PANGAEA database (http://doi.pangaea.de/10.1594/PANGAEA. 853814), and the microscopic charcoal record can be found on the Global Charcoal Database (GCD; www.paleofire.org). 
Acknowledgements. This study is a contribution to the Lake Van Drilling Project PALEOVAN funded by the International Continental Scientific Drilling Program (ICDP), the Swiss National Science Foundation (SNF) and the Scientific and Technological Research Council of Turkey (Tübitak). Financial support was provided by the German Research Foundation (DFG; LI 582/15-1-2). We thank the scientific PALEOVAN team for their support during the sampling campaign, and for sharing data. We kindly thank Ulla Röhl, Alex Wülbers and Hans-Joachim Wallrabe-Adams from the IODP Core Repository in Bremen (MARUM) for their help during the sampling campaign. We thank Nils Andersen and his working team at the Leibnitz-Laboratory for Radiometric Dating and Isotope Research for the measurements of the oxygen isotope samples. N. Pickarski thanks Karen Schmeling and Beate Söntgerath for the pollen preparation, Manuela Rüßmann and Hannah Vossel for their support in the lab, and all colleagues from the Department of Paleobotany. The authors are grateful to Dominik Fleitmann for editing of the manuscript. Laura Sadori and an anonymous reviewer are acknowledged for their constructive comments and useful recommendations, which improved the quality of this manuscript.

Edited by: D. Fleitmann

\section{References}

Akçar, N. and Schlüchter, C.: Paleoglaciations in Anatolia: A Schematic Review and First Results, Eiszeitalter und Gegenwart, 55, 102-121, 2005.

Allen, J. R., Brandt, U., Brauer, A., Hubberten, H.-W., Huntley, B., Keller, J., Kraml, M., Mackensen, A., Mingram, J., and Negendank, J. F.: Rapid environmental changes in southern Europe during the last glacial period, Nature, 400, 740-743, 1999.

Allen, J. R. M., Watts, W. A., and Huntley, B.: Weichselian palynostratigraphy, palaeovegetation and palaeoenvironment; the record from Lago Grande di Monticchio, southern Italy, EDLP - Med Special, 73/74, 91-110, 2000.

Alvarez-Solas, J. and Ramstein, G.: On the triggering mechanism of Heinrich events, Proc. Natl. Acad. Sci., 108, E1359-E1360, 2011.

Berger, A.: Long-term variations of daily insolation and Quaternary climate changes, J. Atmos. Sci., 35, 2362-2367, 1978.

Berger, A., Loute, M. F., Kaspar, F., and Lorenz, S. J.: Insolation During Interglacial, in: The Climate of Past Interglacial, edited by: Sirocko, F., Claussen, M., Sánchez Goñi, M. F., and Litt, T., Elsevier, Amsterdam, 13-27, 2007.

Berglund, B. E. and Ralska-Jasiewiczowa, M.: Pollen anaylsis and pollen diagrams, in: Handbook of Holocene Paleoecology and Palaeohydrology, edited by: Berglund, B. E. and RalskaJasiewiczowa, M., John Wiley and Sons, 455-484, 1986.

Beug, H.-J.: Leitfaden der Pollenbestimmung für Mitteleuropa und angrenzende Gebiete, Pfeil, München, 2004.

Blunier, T. and Brook, E. J.: Timing of Millennial-Scale Climate Change in Antarctica and Greenland During the Last Glacial Period, Science, 291, 109-112, 2001.

Böhm, E., Lippold, J., Gutjahr, M., Frank, M., Blaser, P., Antz, B., Fohlmeister, J., Frank, N., Andersen, M. B., and Deininger, M.: Strong and deep Atlantic meridional overturning circulation during the last glacial cycle, Nature, 517, 73-76, 2015.
Bond, G. C. and Lotti, R.: Iceberg Discharges into the North Atlantic on Millennial Time Scales During the Last Glaciation, Science, 267, 1005-1010, 1995.

Bond, G. C., Heinrich, H., Broecker, W.S., Labeyrie, L., McManus, J., Andrews, J., Huon, S., Jantschik, R., Clasen, S., Simet, C., Tedesco, K., Klas, M., Bonani, G., and Ivy, S.: Evidence for massive discharges of icebergs into the North Atlantic ocean during the last glacial period, Nature, 360, 245-249, 1992.

Bond, G. C., Broecker, W. S., Johnsen, S., McManus, J., Labeyrie, L., Jouzel, J., and Bonani, G.: Correlations between climate records from North Atlantic sediments and Greenland ice, Nature, 365, 143-147, 1993.

Bottema, S.: A late quaternary pollen diagram from Lake Urmia (Northwestern Iran), Rev. Palaeobot. Palynol., 47, 241-261, 1986.

Broecker, W. S.: Massive iceberg discharges as triggers for global climate change, Nature 372, 421-424, 1994.

Cacho, I., Grimalt, J. O., Pelejero, C., Canals, M., Sierro, F. J., Flores, J. A., and Shackleton, N.: Dansgaard-Oeschger and Heinrich event imprints in Alboran Sea paleotemperatures, Paleoceanography, 14, 698-705, 1999.

Cacho, I., Grimalt, J. O., Sierro, F. J., Shackleton, N. J. S., and Canals, M.: Evidence for enhanced Mediterranean thermohaline circulation during rapid climatic coolings, Earth Planet. Sci. Lett., 183, 417-429, 2000.

Chapman, M. R. and Shackleton, N. J.: Global ice-volume fluctuations, North Atlantic ice-rafting events, and deep-ocean circulation changes between 130 and $70 \mathrm{ka}$, Geology, 27, 795-798, 1999.

Clark, J. S., Lynch, J., Stocks, B. J., and Goldammer, J. G.: Relationships between charcoal particles in air and sediments in westcentral Siberia, The Holocene 8, 19-29, 1998.

Daniau, A.-L., Harrison, S. P., and Bartlein, P. J.: Fire regimes during the Last Glacial, Quaternary Sci. Rev., 29, 2918-2930, 2010.

Dansgaard, W., Johnsen, S. J., Clausen, H. B., Dahl-Jensen, D., Gundestrup, N. S., Hammer, C. U., Hvidberg, C. S., Steffensen, J. P., Sveinbjörnsdottir, A. E., Jouzel, J., and Bond, G.: Evidence for general instability of past climate from a 250-kyr ice-core record, Nature, 364, 218-220, 1993.

Degens, E. T. and Kurtman, F.: The Geology of Lake Van, The Mineral Research and Exploration Institute of Turkey, Ankara, 1978.

Faegri, K. and Iversen, J.: Bestimmungsschlüssel für die nordwesteuropäische Pollenflora, Gustav Fischer, Jena, 1993.

Fletcher, W. J., Sánchez Goñi, M. F., Allen, J. R. M., Cheddadi, R., Combourieu-Nebout, N., Huntley, B., Lawson, I., Londeix, L., Magri, D., Margari, V., Müller, U. C., Naughton, F., Novenko, E., Roucoux, K., and Tzedakis, P. C.: Millennial-scale variability during the last glacial in vegetation records from Europe, Vegetation Response to Millennial-scale Variability during the Last Glacial, 29, 2839-2864, 2010.

Follieri, M., Giardini, M., Magri, D., and Sadori, L.: Palynostratigraphy of the last glacial period in the volcanic region of central italy, Quaternary Internat., 47/48, 3-20, 1998.

Frey, W. and Kürschner, H.: Die Vegetation im Vorderer Orient, Erläuterungen zur Karte A VI 1 Vorderer Orient, Vegetation des "Tübinger Atlas des Vorderen Orients", edited by: Reihe, A., Tübinger Atlas des Vorderen Orients, Wiesbaden, 1989. 
Heinrich, H.: Origin and consequences of cyclic ice rafting in the Northeast Atlantic Ocean during the past 130000 years, Quaternary Res., 29, 142-152, 1988.

Hemming, S. R.: Heinrich events: Massive late Pleistocene detritus layers of the North Atlantic and their global climate imprint, Rev. Geophys., 42, RG1005, doi:10.1029/2003RG000128, 2004.

Hodell, D. A., Channell, J. E. T., Curtis, J. H., Romero, O. E., and Röhl, U.: Onset of "Hudson Strait" Heinrich events in the eastern North Atlantic at the end of the middle Pleistocene transition $(\sim 640 \mathrm{ka})$ ?, Paleoceanography, 23, PA4218, doi:10.1029/2008PA001591, 2008.

Jessen, A. and Milthers, V.: Stratigraphical and paleontological studies of interglacial freshwater deposits in Jutland and Northwest Germany, Danmarks Geologiske Undersøgelse 48, 1-379, 1928.

Kwiecien, O., Arz, H. W., Lamy, F., Plessen, B., Bahr, A., and Haug, G. H.: North Atlantic control on precipitation pattern in the eastern Mediterranean/Black Sea region during the last glacial, Quaternary Res., 71, 375-384, 2009.

Kwiecien, O., Stockhecke, M., Pickarski, N., Heumann, G., Litt, T., Sturm, M., Anselmetti, F., Kipfer, R., and Haug, G. H.: Dynamics of the last four glacial terminations recorded in Lake Van, Turkey, Quaternary Sci. Rev., 104, 42-52, 2014.

Langgut, D., Almogi-Labin, A., Bar-Matthews, M., and WeinsteinEvron, M.: Vegetation and climate changes in the South Eastern Mediterranean during the Last Glacial-Interglacial cycle (86 ka): new marine pollen record, Quaternary Sci. Rev., 30, 3960-3972, 2011.

Lemcke, G. and Sturm, M.: $\delta^{18} \mathrm{O}$ and Trace Element Measurements as Proxy for the Reconstruction of Climate Changes at Lake Van (Turkey): Preliminary Results, in: Third Millennium BC Climate Change and Old World Collapse, edited by: Dalfes, H. N., Kukla, G., and Weiss, H., NATO ASI Series, Springer Berlin Heidelberg, 653-678, 1997.

Leroy, S. A. G. and Arpe, K.: Glacial refugia for summer-green trees in Europe and south-west Asia as proposed by ECHAM3 time-slice atmospheric model simulations, J. Biogeogr., 34, 2115-2128, 2007.

Lézine, A.-M., von Grafenstein, U., Andersen, N., Belmecheri, S., Bordon, A., Caron, B., Cazet, J.-P., Erlenkeuser, H., Fouache, E., Grenier, C., Huntsman-Mapila, P., Hureau-Mazaudier, D., Manelli, D., Mazaud, A., Robert, C., Sulpizio, R., Tiercelin, J.-J., Zanchetta, G., and Zeqollari, Z.: Lake Ohrid, Albania, provides an exceptional multi-proxy record of environmental changes during the last glacial-interglacial cycle, Palaeogeogr. Palaeoclimatol. Palaeoecol., 287, 116-127, 2010.

Litt, T. and Anselmetti, F. S.: Lake Van deep drilling project PALEOVAN, Quaternary Sci. Rev., 104, 1-7, 2014.

Litt, T., Krastel, S., Sturm, M., Kipfer, R., Örcen, S., Heumann, G., Franz, S. O., Ülgen, U. B., and Niessen, F.: "PALEOVAN", International Continental Scientific Drilling Program (ICDP): site survey results and perspectives, Quaternary Sci. Rev., 28, 15551567, 2009.

Litt, T., Anselmetti, F. S., Baumgarten, H., Beer, J., Çagatay, N., Cukur, D., Damci, E., Glombitza, C., Haug, G., Heumann, G., Kallmeyer, J., Kipfer, R., Krastel, S., Kwiecien, O., Meydan, A. F., Orcen, S., Pickarski, N., Randlett, M.-E., Schmincke, H.-U., Schubert, C. J., Sturm, M., Sumita, M., Stockhecke, M., Tomonaga, Y., Vigliotti, L., Wonik, T., and the PALEOVAN scientific team: 500000 Years of Environmental History in Eastern Anatolia: The PALEOVAN Drilling Project, Sci. Drill. J., 14, 18-29, 2012.

Litt, T., Pickarski, N., Heumann, G., Stockhecke, M., and Tzedakis, P. C.: A 600000 year long continental pollen record from Lake Van, eastern Anatolia (Turkey), Quaternary Sci. Rev., 104, 3041, 2014.

Lowe, J. J. and Walker, M. J. C.: Reconstructing Quaternary Environments, 2nd Edn. Longman, Edinburgh, 1984.

McManus, J. F., Oppo, D. W., and Cullen, J. L.: A 0.5-MillionYear Record of Millennial-Scale Climate Variability in the North Atlantic, Science, 283, 971-975, 1999.

Moore, P. D., Webb, J. A., and Collinson, M. E.: Pollen Analysis, Blackwell Science, 1991.

Müller, U. C., Pross, J., Tzedakis, P. C., Gamble, C., Kotthoff, U., Schmiedl, G., Wulf, S., and Christanis, K.: The role of climate in the spread of modern humans into Europe, Quaternary Sci. Rev., 30, 273-279, 2011.

NGRIP members: High-resolution record of Northern Hemisphere climate extending into the last interglacial period, Nature, 431, 147-151, 2004.

Panagiotopoulos, K., Böhm, A., Leng, M., Wagner, B., and Schäbitz, F.: Climate variability over the last $92 \mathrm{ka}$ in SW Balkans from analysis of sediments from Lake Prespa, Clim. Past, 10, 643660, doi:10.5194/cp-10-643-2014, 2014.

Pickarski, N., Kwiecien, O., Djamali, M., and Litt, T.: Vegetation and environmental changes during the last interglacial in eastern Anatolia (Turkey): a new high-resolution pollen record from Lake Van, Palaeogeogr. Palaeoclimatol. Palaeoecol., 435, 145158, 2015.

Punt, W.: The Northwest European Pollen Flora, Elsevier, Amsterdam, 1976.

Rasmussen, S. O., Andersen, K. K., Svensson, A. M., Steffensen, J. P., Vinther, B. M., Clausen, H. B., Siggaard-Andersen, M.L., Johnsen, S. J., Larsen, L. B., Dahl-Jensen, D., Bigler, M., Röthlisberger, R., Fischer, H., Goto-Azuma, K., Hansson, M. E., and Ruth, U.: A new Greenland ice core chronology for the last glacial termination, J. Geophys. Res.-Atmos., 111, D06102, doi:10.1029/2005JD006079, 2006.

Rasmussen, S. O., Bigler, M., Blockley, S. P., Blunier, T., Buchardt, S. L., Clausen, H. B., Cvijanovic, I., Dahl-Jensen, D., Johnsen, S. J., Fischer, H., Gkinis, V., Guillevic, M., Hoek, W. Z., Lowe, J. J., Pedro, J. B., Popp, T., Seierstad, I. K., Steffensen, J. P., Svensson, A. M., Vallelonga, P., Vinther, B. M., Walker, M. J. C., Wheatley, J. J., and Winstrup, M.: A stratigraphic framework for abrupt climatic changes during the Last Glacial period based on three synchronized Greenland ice-core records: refining and extending the INTIMATE event stratigraphy, Quaternary Sci. Rev., 106, 14-28, 2014.

Reille, M.: Pollen et Spores d'Europe et d'Afrique du Nord (Supplement 1), Laboratoire de Botanique Historique et Palynologie, Marseille, 1995.

Reille, M.: Pollen et Spores d'Europe et d'Afrique du Nord (Supplement 2), Laboratoire de Botanique Historique et Palynologie, Marseille, 1998.

Reille, M.: Pollen et Spores d'Europe et d'Afrique du Nord, Laboratoire de Botanique Historique et Palynologie, Marseille, 1999.

Roberts, N., Jones, M. D., Benkaddour, A., Eastwood, W. J., Filippi, M. L., Frogley, M. R., Lamb, H. F., Leng, M. J., Reed, J. 
M., Stein, M., Stevens, L., Valero-Garcés, B., and Zanchetta, G.: Stable isotope records of Late Quaternary climate and hydrology from Mediterranean lakes: the ISOMED synthesis., Quaternary Sci. Rev., 27, 2426-2441, 2008.

Sadori, L., Masi, A., and Ricotta, C.: Climate-driven past fires in central Sicily, Plant Biosys., 149, 166-173, 2015.

Sánchez Goñi, M. F., Cacho, I., Turon, J.-L., Guiot, J., Sierro, F. J., Peypouquet, J.-P., Grimalt, J. O., and Shackleton, N. J.: Synchroneity between marine and terrestrial responses to millennial scale climatic variability during the last glacial period in the Mediterranean region, Clim. Dynam., 19, 95-105, 2002.

Sánchez Goñi, M. F. and Harrison, S. P.: Introduction: Millennialscale climate variability and vegetation changes during the Last Glacial: Concepts and terminology, Quaternary Sci. Rev., 29, 2823-2827, 2010.

Shackleton, N. J.: Oxygen isotopes, ice volume and sea level, Quaternary Sci. Rev., 6, 183-190, 1987.

Shumilovskikh, L. S., Tarasov, P., Arz, H. W., Fleitmann, D., Marret, F., Nowaczyk, N., Plessen, B., Schlütz, F., and Behling, H.: Vegetation and environmental dynamics in the southern Black Sea region since $18 \mathrm{kyr}$ BP derived from the marine core 22GC3, Palaeogeogr. Palaeoclimatol. Palaeoecol., 337/338, 177193, 2012.

Shumilovskikh, L. S., Fleitmann, D., Nowaczyk, N. R., Behling, H., Marret, F., Wegwerth, A., and Arz, H. W.: Orbitaland millennial-scale environmental changes between 64 and $20 \mathrm{ka}$ BP recorded in Black Sea sediments, Clim. Past, 10, 939954, doi:10.5194/cp-10-939-2014, 2014.

Stockhecke, M., Kwiecien, O., Vigliotti, L., Litt, T., Pickarski, N., Schmincke, H.-U., and Çağatay, N.: Chronology of the $600 \mathrm{ka}$ old long continental record of Lake Van: climatostratigraphic synchronization and dating, Quarternary Sci. Rev., 104, 8-17, 2014a.

Stockhecke, M., Sturm, M., Brunner, I., Schmincke, H., Sumita, M., Kipfer, R., Cukur, D., Kwiecien, O., and Anselmetti, F. S.: Sedimentary evolution and environmental history of Lake Van (Turkey) over the past 600000 years, Sedimentology, 61, 18301861, 2014b.

Stockmarr, J.: Tablets with spores used in absolute pollen analysis, Pollen et Spores, 13, 615-621, 1971.

Sumita, M. and Schmincke, H.-U.: Impact of volcanism on the evolution of Lake Van II: Temporal evolution of explosive volcanism of Nemrut Volcano (eastern Anatolia) during the past ca. 0.4 Ma, J. Volcanol. Geotherm. Res., 253, 15-34, 2013.

Svensson, A., Andersen, K. K., Bigler, M., Clausen, H. B., DahlJensen, D., Davies, S. M., Johnsen, S. J., Muscheler, R., Rasmussen, S. O., Röthlisberger, R., Peder Steffensen, J., and Vinther, B. M.: The Greenland Ice Core Chronology 2005, 15$42 \mathrm{ka}$ - Part 2: comparison to other records, Crit. Quat. Stratigr., 25, 3258-3267, 2006.

Svensson, A., Andersen, K. K., Bigler, M., Clausen, H. B., DahlJensen, D., Davies, S. M., Johnsen, S. J., Muscheler, R., Parrenin, F., Rasmussen, S. O., Röthlisberger, R., Seierstad, I., Steffensen, J. P., and Vinther, B. M.: A 60000 year Greenland stratigraphic ice core chronology, Clim. Past, 4, 47-57, doi:10.5194/cp-4-47$2008,2008$.
Tinner, W., Conedera, M., Ammann, B., Gaggeler, H. W., Gedye, S., and Jones, R., Sagesser, B.: Pollen and charcoal in lake sediments compared with historically documented forest fires in southern Switzerland since AD 1920, The Holocene, 8, 31-42, 1998.

Tükeş, M.: Meteorological Drought in Turkey: A Historical Perspective, 1930-93, Drought Network News (1994-2001), 84, 1996.

Tzedakis, P. C.: Hierarchical biostratigraphical classification of long pollen sequences, J. Quat. Sci., 9, 257-259, 1994.

Tzedakis, P. C.: Towards an understanding of the response of southern European vegetation to orbital and suborbital climate variability, Quaternary Sci. Rev., 24, 1585-1599, 2005.

Tzedakis, P. C.: Seven ambiguities in the Mediterranean palaeoenvironmental narrative, Quaternary Sci. Rev.,26, 2042-2066, 2007.

Tzedakis, P. C., Lawson, I. T., Frogley, M. R., Hewitt, G. M., and Preece, R. C.: Buffered Tree Population Changes in a Quaternary Refugium: Evolutionary Implications, Science, 297, 2044-2047, 2002.

Tzedakis, P. C., Frogley, M. R., Lawson, I. T., Preece, R. C., Cacho, I., and de Abreu, L.: Ecological thresholds and patterns of millennial-scale climate variability: The response of vegetation in Greece during the last glacial period, Geol. Soc. Am., 32, 109112,2004

Vanniere, B., Power, M.J., Roberts, N., Tinner, W., Carrión, J., Magny, M., Bartlein, P., Colombaroli, D., Daniau, A.L., Finsinger, W., Gil-Romera, G., Kaltenrieder, P., Pini, R. Sadori, L., Turner, R., Valsecchi, V., and Vescovi, E.: CircumMediterranean fire activity and climate changes during the mid-Holocene environmental transition (8500-2500 cal. BP), Holocene, 21, 53-73, 2011.

van Zeist, W. and Bottema, S.: Palynological investigations in western Iran, Palaeohistoria Bussum, 19, 19-85, 1977.

Vigliotti, L., Channell, J. E. T., and Stockhecke, M.: Paleomagnetism of Lake Van sediments: chronology and paleoenvironment since 350 ka, Quaternary Sci. Rev., 104, 18-29, 2014.

Wick, L., Lemcke, G., and Sturm, M.: Evidence of Lateglacial and Holocene climatic change and human impact in eastern Anatolia: high resolution pollen, charcoal, isotopic and geochemical records from the laminated sediments of Lake Van, The Holocene 13, 665-675, 2003.

Wolff, E. W., Chappellaz, J., Blunier, T., Rasmussen, S. O., and Svensson, A.: Millennial-scale variability during the last glacial: The ice core record, Vegetation Response to Millennial-scale Variability during the Last Glacial, 29, 2828-2838, 2010.

Zohary, M.: Geobotanical Foundations of the Middle East, Gustav Fischer Verlag, Swets and Zeitlinger, Stuttgart, Amsterdam, 1973. 